\title{
Jurnal Biotek
}

p-ISSN: 2581-1827 (print), e-ISSN: 2354-9106 (online)

Website: http://journal.uin-alauddin.ac.id/index.php/biotek/index

\section{KORELASI MOTIVASI DENGAN HASIL BELAJAR SELAMA PANDEMI COVID 19 PADA PESERTA DIDIK KELAS MIA XI}

Nurfathurrahmah*, Ariyansyah, Erni Suryani, Olahairullah

Sekolah Tinggi Keguruan dan Ilmu Pendidikan Bima, Indonesia

* Correspondence email: nurfathurrahmah_bio@stkipbima.ac.id

\begin{tabular}{ll}
\hline ARTICLE & INFO \\
\hline \multicolumn{2}{l}{ Article History } \\
Received & $: 15-11-2021$ \\
Accepted & $: 24-12-2021$ \\
Published & $: 31-12-2021$
\end{tabular}

Keywords:

motivation, learning outcomes, covid-19 pandemic

\section{ABSTRAK}

Suasana pembelajaran di masa sekarang mengharuskan kegiatan belajar dilaksanakan secara tatap muka dalam waktu dan jarak dibatasi serta daring, hal ini turut berdampak pada motivasi dengan hasil belajar peserta didik. Penelitian ini bertujuan untuk melihat korelasi motivasi dengan hasil belajar selama pandemi covid-19 pada peserta didik kelas MIA XI dari sisi korelasi. Jenis penelitian ex post facto, Jumlah sampel 24 peserta didik dari keseluruhan 3 kelas MIA XI menggunakan teknik Non-Random Sample dilakukan secara Accidental Sampling. Instrumen penelitian lembar angket dan soal tes essay, data dianalisis menggunakan rumus korelasi product moment dengan bantuan aplikasi SPSS 16.0 for windows. Hasil analisis data menunjukkan nilai $r_{\text {hitung }}$ lebih kecil dari $r_{\text {tabel }}(0,196<0,404)$, maka hipotesis nol (HO) dalam penelitian ini diterima dan hipotesis kerja (H1) ditolak. Hasil analisis korelasi product moment menunjukkan angka korelasi sebesar 0,196, berdasarkan interpretasi koefisien korelasi 0,00 - 0,199 maka dinyatakan memiliki hubungan sangat lemah/rendah. Maka dapat dinyatakan bahwa korelasi motivasi dengan hasil belajar selama pandemi covid 19 pada peserta didik kelas MIA XI dikategorikan lemah atau rendah. Hal ini menunjukkan bahwa adanya korelasi motivasi dengan hasil belajar dapat dipengaruhi oleh banyak faktor, diantaranya sistem pembelajaran daring, metode mengajar, intensitas belajar, minat, sumber belajar, lingkungan sekolah dan lingkungan keluarga.

ABSTRACT: The learning process is undertaken both online and faceto-face during the pandemic. But it is constrained by time constraints and physical distance. As a result, student motivation and learning results are affected. This ex post facto research aimed to correlate the motivation toward learning outcomes during the covid-19 pandemic in MIA XI class students. The number of samples was 24 students from all 3 MIA XI classes using the Non-Random Sample technique. The instruments were a questionnaire sheet and an essay test. Data were analyzed using the product-moment correlation formula as SPSS 16.0 application for windows. The results of data analysis show that the value of rcount is smaller than rtable $(0.196<0.404)$, then the null hypothesis (HO) in this study is accepted and the working hypothesis (H1) is rejected. The correlation number from product-moment correlation analysis is 0.196. Based on the interpretation of the correlation coefficient. 0.00 - 0.199 means a very weak relationship. It appears that the correlation of motivation with learning outcomes 
during the covid 19 pandemic in MIA XI class students is weak. In other words, the correlation between motivation and learning outcomes can be influenced by many factors. The factors could be an online learning system, teaching methods, learning intensity, interests, learning resources, school environment, and family.

\section{PENDAHULUAN}

Tantangan yang dihadapi di masa pandemi menuntun pendidik untuk terus berinovasi dalam mendukung keberlangsungan proses pembelajaran agar tetap terlaksana, dalam hal ini kreativitas tentunya sangat diperlukan salah satunya menggunakan teknologi untuk menunjang pembelajaran daring (online). Diperkuat oleh Direktur Jenderal Pendidikan Tinggi Kemendikbud "penggunaan teknologi bukan hanya transmisi pengetahuan, tetapi juga memastikan pembelajaran tetap tersampaikan dengan baik serta dapat membawa mahasiswa dan pelajar memiliki keterampilan, berkompeten serta mengedukasi belajar mandiri di abad ke-21" (Hendayana, 2020).

Situasi pembelajaran online tentunya sangat berpengaruh terhadap motivasi apakah dapat menstimulasi hasil belajar atau sebaliknya. Apalagi motivasi merupakan salah satu faktor paling utama untuk diperhatikan oleh guru dalam berjalan efektifnya pembelajaran. Menurut Sudibyo, Jatmiko, \& Widodo (2016) bahwa tingginya kemampuan kognitif siswa terlihat dari termotivasinya mempelajari serta berusaha untuk memahami materi lebih baik.

Kondisi pembelajaran peserta didik kelas MIA XI Sekolah Menengah Atas Negeri 3 Kota Bima tahun ajaran 2020/2021 selama wabah virus corona, terlihat berkurangnya jumlah peserta didik yang ikut proses pembelajaran di sekolah maupun daring jika dibandingkan dengan situasi belajar sebelumnya serta terbatasnya waktu proses belajar tatap muka hanya dilaksanakan 2 kali dalam seminggu dimulai jam 07.30 sampai 10.00, dalam 1 hari hanya diisi 1 mata pelajaran saja, selebihnya pembelajaran dilakukan secara daring serta belajar mandiri yaitu membaca buku paket, membuat resume atau tugas dalam bentuk lainnya.

Situasi demikian memunculkan efek bagi karakteristik pembelajaran, pendidik dan peserta didik pada awalnya terbiasa leluasa beraktivitas seperti melakukan diskusi kelompok secara langsung bertatap muka di ruangan kelas kini beralih menggunakan aplikasi Whatsapp dan berkunjung di rumah siswa. Penuturan (Kurniawan \& Rohmat, 2021) pelaksanaan pembelajaran waktu normalnya 40 menit namun pada saat daring hanya 30 menit, sebelum memulai daring siswa terlebih dahulu dikirimkan materi dan 
diinformasikan bahwa proses belajar mengajar akan dimulai, tidak maksimalnya siswa dalam mengumpulkan tugas, minimnya komunikasi dua arah serta interaksi langsung antara guru dan siswa hingga biaya belajar online yang dikeluhkan mahal. Pendidik diharapkan memberikan bimbingan terbaik, menghadirkan suasana menyenangkan dalam mentransferkan ilmu pengetahuan, serta kreativitas mengaplikasikan perangkat pembelajaran sehingga menunjang proses kegiatan belajar berjalan dengan baik dan dapat meningkatkan mutu pendidikan.

Selain kondisi pembelajaran, motivasi belajar siswa juga berpengaruh dalam keberhasilan pembelajaran. Hal ini sesuai dengan yang diungkapkan oleh Emda (2017) bahwa proses pembelajaran akan mencapai keberhasilan apabila siswa memiliki motivasi belajar yang baik. Oleh karena itu motivasi belajar sangat penting untuk dimiliki oleh setiap siswa, baik motivasi intrinsik maupun ekstrinsik. Menerapkan model pembelajaran yang bervariasi menjadi kekuatan tersendiri bagi peserta didik untuk terus termotivasi mengajar (Widayanti, \& Sukirno, 2018). Suasana belajar jarak jauh ikut serta mendorong semangat belajar siswa, bila dilaksanakan secara berkesinambungan untuk melatih kemandirian baik dalam memahami materi maupun berpikir kritis (Sari \& Rusmin, 2018). Mengingat pentingnya motivasi menjadi bagian faktor penyebab belajar, hal ini sejalan dengan pendapat Arifin (2017) berkembang dan melemahnya wawasan berkesinambungan terhadap adanya motivasi pada diri seseorang. Tujuan yang diharapkan dalam penelitian mengetahui kedudukan dalam hal ini dari sisi tingkat korelasi motivasi dengan hasil belajar selama pademi covid 19 pada peserta didik kelas MIA XI.

\section{METODE PENELITIAN}

Penelitian korelasi dengan jenis penelitian expost facto meliputi variabel $\mathrm{X}$ yaitu motivasi, Y yaitu hasil belajar siswa yang dirancang dengan pendekatan deskriptif kuantitatif bertujuan untuk mendapatkan gambaran korelasi antara motivasi dan hasil belajar. Populasinya peserta didik MIA kelas XI SMAN 3 Kota Bima yang berjumlah sebanyak 68 siswa. Teknik pengambilan sampel Non-Random Sample dilakukan secara Accidental Sampling dikarena jumlah peserta didik pada tiap kelas sedikit yang hadir sehingga ditetapkanlah jumlah sampel 24 peserta didik dari keseluruhan 3 kelas MIA XI. Instrumen berupa lembar angket tertutup sebanyak 25 pernyataan untuk mendapatkan data motivasi sedangkan hasil belajar diperoleh dari tiga nomor soal essay materi sel. 
Teknik menganalisis data memilih rumus korelasi product moment berbantuan aplikasi Statistikal Package for the Social Sciences 16.0 for windows. H0 : Tidak ada hubungan antar variabel H1: Ada hubungan antar variabel. Pengambilan Keputusan; jika nilai $r_{\text {hitung }}$ $<\mathrm{r}_{\text {tabel }}$ maka H0 diterima sebaliknya jika $\mathrm{r}_{\text {hitung }}<\mathrm{r}_{\text {tabel }}$ maka H0 ditolak dan menurut Sugiyono (2016), koefisien korelasi dapat diinterpretasikan berdasarkan pedoman sebagai berikut, interval koefisien 0,00-0,199 tingkat hubungan sangat rendah, 0,20-0,399 tingkat hubungan rendah, 0,40-0,599 sedang, 0,60-0,799 kuat, 0,80-1,000 sangat kuat.

\section{HASIL DAN PEMBAHASAN}

Secara umum data tentang motivasi belajar siswa dapat diketahui dari angket yang peruntukan 24 peserta didik sebagai responden. Data angket tersebut dianalisis kemudian ditentukan kategori motivasi belajar. Adapun data tersebut dapat dilihat pada Tabel 1.

Tabel 1. Data Analisis Motivasi Belajar Siswa

\begin{tabular}{lccc}
\hline \multicolumn{1}{c}{ Kategori } & Interval & Frekuensi & Persentase \\
\hline Tinggi & $76-100$ & 11 & 45,8 \\
Sedang & $51-75$ & 9 & 37,5 \\
Rendah & $25-50$ & 4 & 25 \\
\hline
\end{tabular}

Agar lebih mudah memahami distribusi data motivasi belajar peserta didik, maka ditampilkan dalam bentuk diagram seperti pada Gambar 1 berikut.

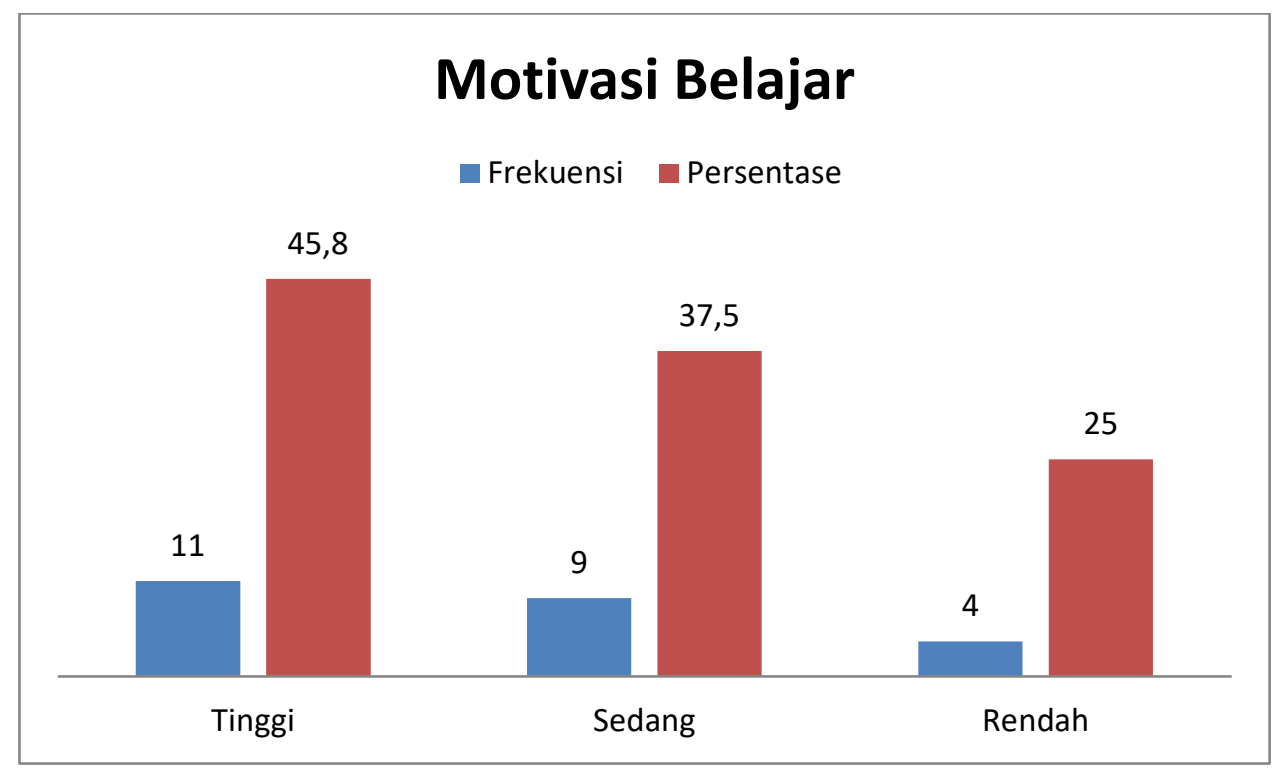

Gambar 1. Data Motivasi Belajar Peserta Didik MIA XI SMA Negeri 3 Kota Bima

Tabel 1 dan gambar 1 menunjukkan bahwa 24 peserta didik MIA XI SMA Negeri

3 Kota Bima memperoleh motivasi belajar kategori tinggi 11 (45,8\%), kategori sedang 9 $(37,5 \%)$ dan kategori rendah 4 (25\%). 
Adapun data hasil belajar peserta didik ditentukan berdasarkan skor yang diperoleh dibagi skor maksimal yang telah ditentukan. Kemudian dinyatakan dalam tabel kriteria hasil belajar yang dapat dilihat pada Tabel 2 dibawah ini.

Tabel 2. Data Analisis Hasil Belajar Peserta Didik

\begin{tabular}{lccc}
\hline Kategori & Interval & Frekuensi & Persentase \\
\hline Sangat tinggi & $85-100$ & 5 & $31,3 \%$ \\
Tinggi & $70-84$ & 11 & $45,8 \%$ \\
Cukup & $60-69$ & 6 & $25,0 \%$ \\
Rendah & $51-59$ & 2 & $8,3 \%$ \\
Sangat rendah & $0-50$ & 0 & $0,0 \%$ \\
\hline
\end{tabular}

Agar lebih mudah memahami distribusi data motivasi belajar peserta didik kelas XI MIA dapat ditampilkan berbentuk diagram seperti pada Gambar 2 berikut.

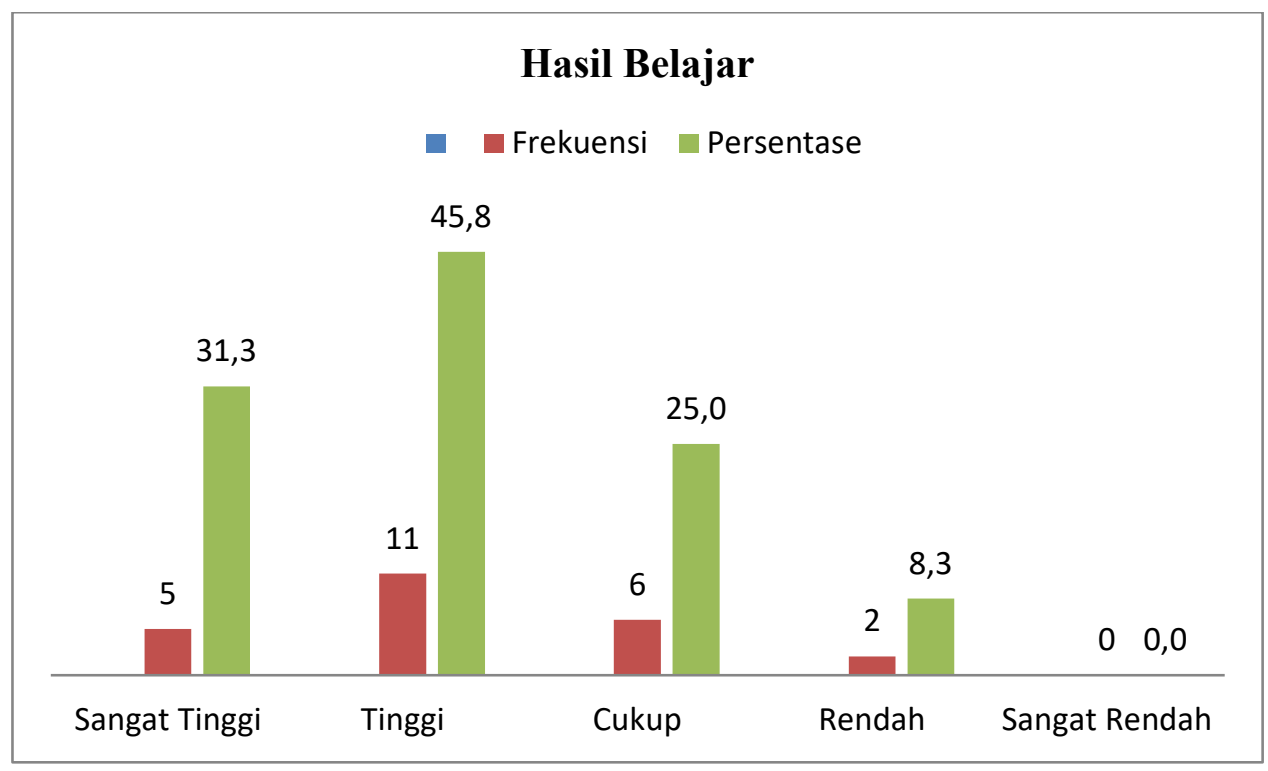

Gambar 2. Diagram Data Hasil Belajar Peserta Didik MIA XI SMA Negeri 3 Kota Bima.

Data hasil belajar pada tabel dan gambar 1, menunjukkan 5 peserta didik (31,3\%) berada di kategori sangat tinggi, 11 peserta didik (45,8\%) dikategorikan tinggi, 6 peserta didik (25,0\%) dikategorikan cukup, dan 2 peserta didik $(8,3 \%)$ dikategorikan rendah. Setelah dihitung data motivasi dan hasil belajar peserta didik dapat dinyatakan bahwa pada kategori tinggi menempati jumlah dan persentase lebih besar dibandingkan pada kategori lainnya dimana pada data motivasi belajar kategori tinggi ada 11 peserta didik $(45,8 \%)$ dan data hasil belajar pada kategori tinggi 11 peserta didik $(45,8 \%)$. Hal ini mendefinisikan bahwa meningkat dan menurunnya motivasi belajar berpengaruh terhadap hasil belajar, menurut Wijayanti \& Widodo (2020) ketika peserta didik kuat memotivasi dirinya dalam kegiatan belajar maka hasil yang diperoleh pun sangat optimal. 
Hasil perhitungan dilanjutkan uji hipotesis menggunakan rumus korelasi Product Moment dari Karl Pearson dibantu aplikasi SPSS 16.0 for windows. Adapun hasil uji hipotesis menggunakan analisis korelasi Product Moment dari Karl Pearson adalah sebagai berikut.

Tabel 3. Hasil Korelasi Product Moment dari Karl Pearson

\begin{tabular}{l|c|c|c}
\hline \multicolumn{1}{c|}{ Variabel } & R hitung & R tabel & Sig \\
\hline $\begin{array}{l}\text { Motivasi belajar } \\
\text { Hasil belajar }\end{array}$ & 0,196 & 0,404 & 0,360 \\
\hline
\end{tabular}

Berdasarkan tabel di atas, maka dapat diketahui bahwa nilai $\mathrm{r}_{\text {hitung }}$ lebih kecil dari $\mathrm{r}_{\text {tabel }}(0,196<0,404)$, maka hipotesis nol (H0) dalam penelitian ini diterima dan hipotesis kerja (H1) ditolak dan hasil analisis korelasi product moment menunjukkan angka korelasi sebesar 0,196, berdasarkan interpretasi koefisien korelasi 0,00 - 0,199 maka dinyatakan memiliki hubungan sangat lemah/rendah (Sugiyono, 2016). Kedua analisis tersebut secara keseluruhan dapat dinyatakan bahwa korelasi antara motivasi dengan hasil belajar selama pandemi covid 19 pada peserta didik kelas MIA XI dikategorikan lemah atau rendah.

Hasil penelitian sejalan dengan data survei yang dilakukan oleh Lukita \& Sudibjo (2021) motivasi belajar siswa dari tahun 2019-2020 mengalami penurunan yaitu dari 3,3 menurun menjadi 2,94 poin, dapat dipresentasikan sebanyak $9 \%$ atau sebesar 0,36 poin. Halidi (2021), 86 persen sulitnya konsentrasi serta 73 persen minimnya keterampilan sosial yang dihadapi anak-anak saat pembelajaran online. Penelitian Cahyani, dkk (2020) ditengah situasi pandemic-virus covid-19 motivasi belajar daring siswa menurun karena nilai signifikansi kurang dari 0,05 serta dipengaruhi oleh kondisi lingkungan belajar yang tidak kondusif, waktu belajar yang tidak tepat serta sulitnya guru mengkondisikan iklim belajar karena terbatasi ruang virtual.

Kegiatan pembelajaran dipengaruhi motivasi belajar peserta didik. Menurut Dina (2020) faktor yang mempengaruhi motivasi belajar diantaranya dapat berasal dari dalam individu (internal) yaitu minat, ekspektasi belajar, dan tujuan belajar. sedangkan faktor eksternal yaitu lingkungan keluarga dan lingkungan sosial. Minat merupakan salah satu pemicu dalam menumbuhkan perasaan senang dan tenang peserta didik dalam menerima materi pelajaran serta lebih memfokuskan konsentrasi pencapaian kemampuan kognitifnya. Menurut Slameto (2015) faktor eksternal lain yang mempengaruhi motivasi belajar dalam keterlibatan orang tua serta skill mengajar guru. Penelitian Lukita \& Sudibjo 
(2021) menunjukkan peran orang tua, kreativitas guru, dan gairah belajar memiliki pengaruh positif terhadap motivasi belajar. Diperkuat oleh Gan \& Sude (2019) bahwa orang tua bekerjasama dengan guru dalam memfasilitasi, mengontrol serta mendampingi peserta didik dalam belajar dan kegiatan lain seperti mematuhi peraturan, mengikuti kegiatan pengembangan diri yang ada di sekolah.

Begitu pula dengan hasil belajar juga terdapat faktor yang mempengaruhinya yaitu IQ, model pembelajaran dan motivasi belajar (Veriansyah, Sarwono, \& Rindarjono, 2018). Hasil belajar pun turut dipengaruhi oleh faktor di dalam sekolah diantaranya kualitas guru, sistem penilaian akademik siswa, implementasi kurikulum serta suasana sekolah sedangkan faktor luar sekolah yaitu keterbatasan fisik, intelektual, infrastruktur dalam masyarakat, serta lingkungan keluarga (Utah State Board of Education, 2019).

Berdasarkan faktor-faktor tersebut, bahwa salah satu yang mempengaruhi belum maksimalnya pencapaian ketuntasan belajar adalah ketepatan memilih model pembelajaran sehingga cara dalam penyampaian materi tidak menarik minat peserta didik untuk bersungguh-sungguh terlibat dalam pembelajaran (Herman, Nurfathurrahmah, Rubianti \& Bakhtiar, 2019), oleh karena demikian sangat cocok menerapkan model Problem Based Learning yang mengharuskan peserta didik belajar mandiri (online) dan pembelajaran melalui tatap muka yang terbatas dalam mengembangkan kemampuan berpikir kritis, menyelesaikan masalah serta keterampilan sosial (Nurfathurrahmah, Suryani, Nehru, \& Olahairullah, 2021). Selain itu mengadopsi praktik belajar melalui bermain merupakan salah satu cara yang efektif dalam memelihara sikap positif terhadap diri sendiri dan menumbuhkan kesadaran dan komitmen diri untuk belajar (Chin, L.C., \& Zakaria, E, 2015). Karena pembelajaran di situasi pandemi mengharuskan dilakukan secara daring tidak seefektif kegiatan pembelajaran tatap muka langsung, beberapa materi harus diuraikan melalui model serta metode pembelajaran. Dalam situasi pandemi sangat memungkinkan diimplementasikan model Problem Based Learning didesain dengan efektif, menarik, mudah dipahami dan menyenangkan bagi peserta didik melalui metode bermain sambil belajar. Kelebihan yang didapat dari implementasi tersebut untuk melatih kemampuan berpikir kreatif, pemecahan masalah, membangun kerjasama, sportivitas, kepercayaan diri dan pembelajaran yang menyenangkan meskipun pembelajaran jarak jauh. 
Rendahnya korelasi antara motivasi dan hasil belajar peserta didik MIA XI SMA Negeri 3 Kota Bima, tidak terlepas dari sistem pembelajaran yang diterapkan di tengah pandemi covid-19. Saat ini suasana belajar mengalami perubahan, dimana pembelajaran di sekolah dilaksanakan dua kali dalam seminggu. Khususnya pada mata pelajaran biologi dilaksanakan sekali dalam seminggu dengan sistem pembelajaran rolling (bergantian jam masuk sekolah) dari jam 07.30-10.00, selanjutnya pembelajaran dilaksanakan melalui luring (kunjungan rumah) masing-masing kelompok belajar akan didatangi oleh guru satu kali dalam seminggu untuk memaksimalkan bimbingan belajar, apabila memungkinkan sesekali dilakukan belajar secara online mengingat faktor penghambat lainnya. Hal ini tentunya berpengaruh terhadap motivasi serta hasil belajar siswa. Kendati demikian pendidik tetap memotivasi peserta didik untuk semangat belajar. Untuk meningkatkan motivasi peserta didik baik pada saat di sekolah maupun kunjungan rumah diterapkan beragam metode yang dipadukan dengan model pembelajaran, memaksimalkan penggunaan sumber belajar serta dorongan eksternal dengan cara mengapresiasi menyelesaikan tugas untuk memperoleh nilai tinggi serta memberikan arahan bagi yang belum mencapai hasil yang maksimal. Hal ini sesuai dengan pendapat Cahyani, Listiana, \& Larasati (2020) bahwa motivasi yang sangat utama di masa pandemi adalah meningkatkan minat siswa dengan bimbingan intens yang disesuaikan sikap pendidik yang ramah tamah serta pujian sehingga siswa tidak merasa tertekan yang artinya merasa nyaman mengikuti pembelajaran. Munculnya motivasi karena terdorong oleh adanya persoalan gejala kejiwaan meliputi perasaan senang juga emosi yang menentukan tingkah laku manusia (Yelvia, 2019). Begitu juga hasil survey tim penjamin mutu FEB UNDIP (2020) bahwa pada perkuliahan daring $61 \%$ dosen menyatakan pembelajaran tersebut tidak efektif dibandingkan pada saat tatap muka di kelas meskipun dosen telah memberikan kesempatan mahasiswa bertanya atau berdiskusi. Hal ini menggambarkan ketidaknyamanan perkuliahan daring bagi sebagian orang.

Pendapat Cahyani, dkk dan Yelvia menggambarkan bahwa adanya korelasi motivasi dengan hasil belajar dapat dipengaruhi oleh banyak faktor, penelitian Gunawan, Kustiani, \& Hariani (2018) menyatakan motivasi tidak berpengaruh secara menyeluruh terhadap hasil belajar. Hasil penelitian Ariyanti, Maulana, \& Damayanti (2021) bahwa motivasi belajar peserta didik terbukti meningkat melalui penerapan metode resitasi dan brainstorming, sedangkan hasil penelitian Angraini, Aminuyati, \& Achmadi, (2016) 
faktor dominan yang mempengaruhi hasil belajar adalah faktor minat dan motivasi belajar dan faktor terkecil yang mempengaruhi hasil belajar adalah faktor ruang kelas. Uraian diatas menunjukkan beberapa faktor lain yang mempengaruhinya yaitu minat belajar, suasana hati, fasilitas belajar, cara pendidik dalam mengajar, lingkungan sekolah maupun keluarga. Faktor- faktor ini harus diperhatikan untuk mewujudkan motivasi dan hasil belajar yang optimal.

\section{KESIMPULAN}

Korelasi antara motivasi dengan hasil belajar selama pandemi covid 19 pada peserta didik kelas MIA XI dikategorikan lemah atau rendah. Dikarenakan motivasi maupun hasil belajar peserta didik turut dipengaruhi oleh proses interaksi yang diterapkan di masa pandemi terbatas dua kali dalam seminggu. Khususnya pada mata pelajaran Biologi dilaksanakan sekali dalam seminggu dengan sistem pembelajaran rolling dari jam 07.30-10.00, selanjutnya pembelajaran dilaksanakan melalui luring (kunjungan rumah) sesekali dilakukan secara online. Faktor minat, kreativitas pendidik dalam mengajar, sumber belajar, lingkungan sekolah dan lingkungan keluarga dapat berpotensi menjadi faktor pendukung tinggi atau rendahnya motivasi dan hasil belajar peserta didik.

\section{DAFTAR PUSTAKA}

Angraini, W. D. (2016). Analisis Faktor-Faktor Yang Mempengaruhi Hasil Belajar Mata Pelajaran Ekonomi Kelas XI IIS SMA. Jurnal Pendidikan dan Pembelajaran Khatulistiwa, 5(8). https://jurnal.untan.ac.id/index.php/jpdpb/article/view/16253.

Arifin, M. I. B. (2017). Pengaruh penerapan teori belajar behavioristik dan prinsipprinsip pembelajaran terhadap motivasi belajar peserta didik smp al-islam gunungpati semarang (Doctoral dissertation, Universitas Negeri Semarang). http://lib.unnes.ac.id/29641/

Ariyanti, A., Maulana, A., \& Damayanti, E. Peningkatan Motivasi Belajar Peserta Didik Melalui Pembelajaran Metode Resitasi Dan Brainstorming. Jurnal Biotek, 9(1), 110. https://doi.org/10.24252/jb.v9i1.17128 .

Cahyani, A., Listiana, I. D., \& Larasati, S. P. D. (2020). Motivasi Belajar Siswa SMA pada Pembelajaran Daring di Masa Pandemi Covid-19. IQ (Ilmu Al-qur'an): Jurnal Pendidikan Islam, 3(01), 123-140. https://doi.org/10.37542/iq.v3i01.57 .

Chin, L. C., \& Zakaria, E. (2015). Effect of game-based learning activities on children's positive learning and prosocial behaviours (Kesan Aktiviti Pembelajaran Berasaskan Permainan terhadap Pembelajaran Positif dan Tingkah Laku Prososial Kanak-Kanak). Jurnal Pendidikan Malaysia (Malaysian Journal of 
Education), 40(2),

159-165.

https://ejournal.ukm.my/jpend/article/viewFile/13236/4171.

Dina, P.A.E. (2020). Faktor-Faktor yang Mempengaruhi Motivasi Belajar Siswa Mata Pelajaran IPS Kelas VIII Madrasah Tsanawiyah Negeri Batu. Skripsi. Diterbitkan. Malang: Fakultas Ilmu Tarbiyah dan Keguruan Universitas Islam Negeri Malik Ibrahim Malang. http://etheses.uin-malang.ac.id/19726/1/16130113Putri\%20Aulia\%20Enan\%20Dina.pdf

Emda, A. (2018). Kedudukan motivasi belajar siswa dalam pembelajaran. Lantanida Journal, 5(2), 172-182. https://jurnal.arraniry.ac.id/index.php/lantanida/article/view/2838/2064 Dina, P.A.E. (2020). Faktor-Faktor yang Mempengaruhi Motivasi Belajar Siswa Mata Pelajaran IPS Kelas VIII Madrasah Tsanawiyah Negeri Batu. Skripsi. Diterbitkan. Malang: Fakultas Ilmu Tarbiyah dan Keguruan Universitas Islam Negeri Malik Ibrahim Malang.

Gan, Y., \& Bilige, S. (2019). Parental involvement in home-based education and children's academic achievement in China. Social Behavior and Personality: an international journal, 47(12), 1-15. https://www.researchgate.net/profile/YongtaoGan-3/publication/338145679 Parental involvement in home-

based_education_and_children's_academic_achievement_in_China/links $/ 5 \mathrm{f} 8114 \mathrm{c}$ 9458515b7cf74cc58/Parental-involvement-in-home-based-education-andchildrens-academic-achievement-in-China.pdf

Gunawan, G., Kustiani, L., \& Sri Hariani, L. (2020). Faktor-Faktor Yang Mempengaruhi Hasil Belajar Siswa. Jurnal Penelitian Dan Pendidikan IPS, 12(1), 14-22. Retrieved from https://ejournal.unikama.ac.id/index.php/JPPI/article/view/4840

Halidi, R. (2021). Survei: 86 Persen Anak Kesulitan Konsentrasi Saat Belajar Daring. Suara.com (https://www.suara.com/health/2021/09/30/182959/survei-86-persenanak-kesulitan-konsentrasi-saat-belajar-daring?page=all, diakses 23 November 2021).

Hendayana, Y. (2020). Tantangan Dunia Pendidikan di Masa Pandemi. Jakarta: Direktorat Jenderal Pendidikan Tinggi Kemendikbud. (https://dikti.kemdikbud.go.id/kabar-dikti/kabar/tantangan-dunia-pendidikan-dimasa-pandemi/, diakses 15 November 2021).

Herman, H., Nurfathurrahmah, N., Rubianti, I., \& Bakhtiar, B. (2019). Model Pembelajaran Inkuiri Terbimbing Terhadap Kemampuan Berpikir Kritis Peserta Didik Mts Darul Hikmah Kota Bima. Jurnal Biotek, 7(2), 136-147. https://doi.org/10.24252/jb.v7i2.11027 .

Kusumaningrini, D. L., \& Sudibjo, N. (2021). Faktor-Faktor Yang Mempengaruhi Motivasi Belajar Siswa Di Era Pandemi Covid-19. Akademika: Jurnal Teknologi Pendidikan, 10(01), 145-161. https://uia.e-journal.id/akademika/article/view/1271 
Nurfathurrahmah, N., Suryani, E., Nehru, N., \& Olahairullah, O. (2021). Perbandingan Hasil Belajar Biologi Model Problem Based Learning Berbantuan LKPD Pokok Bahasan Tulang dan Otot. ORYZA (JURNAL PENDIDIKAN BIOLOGI), 10(1), 2327. https://doi.org/10.33627/oz.v10i1.529.

Kurniawan, N., \& Rohmat, R. (2021). Problematika Pembelajaran Daring Pendidikan Agama Islam Pada Masa Pandemi Covid-19 Di SMP Negeri 2 Sokaraja. Jurnal Ilmiah Mandala Education, 7(4). http://dx.doi.org/10.36312/jime.v7i4.2336.

Sari, D. P., \& Rusmin, A. R. (2018). pengaruh iklim kelas terhadap motivasi belajar peserta didik di sman3 tanjung raja. Jurnal PROFIT Kajian Pendidikan Ekonomi dan Ilmu Ekonomi, 5(1), 80-88. diakses 15 November 2021). http://dx.doi.org/10.36706/jp.v5i1.5639

Slameto. (2015). Belajar dan Faktor-Faktor yang Mempengaruhinya. Jakarta: PT Rineka Cipta.

Sudibyo, E., Jatmiko, B., \& Widodo, W. (2016). Pengembangan instrumen motivasi belajar fisika: angket. Jurnal Penelitian Pendidikan IPA, 1(1), 13-21. https://doi.org/10.26740/jppipa.v1n1.p13-21.

Sugiyono. (2016). Statistika untuk Peneliti. Bandung: Alfabeta.

Tim Penjamin Mutu Fakultas Fakultas Ekonomika dan Bisnis. (2020). Hasil Survei Pembelajaran Daring Masa Pandemi Covid-19 Bagi Dosen di Lingkungan FEB UNDIP Semester Genap 2020. Semarang: FEB UNDIP.

Utah State Board of Education, (2019). Factors Influencing Student Learning. Salt Lake City, Utah: ULEAD Education.

Veriansyah, I., Sarwono, S., \& Rindarjono, M. G. (2018). Hubungan Tingkat Intelegensi (Iq) Dan Motivasi Belajar Geografi Dengan Hasil Belajar Siswa Kelas X Sekolah Menengah Atas Negeri Singkawang Kota Tahun Ajaran 2016/2017. GeoEco, 4(1).

https://journal.unesa.ac.id/index.php/jppipa/article/view/576.

Widayanti, A. (2018). Penerapan Model Pembelajaran Teknik Make A Match Untuk Meningkatkan Motivasi Dan Aktivitas Belajar Siswa. Jurnal Pendidikan Akuntansi Indonesia, 16(1), 57-66. http://dx.doi.org/10.21831/jpai.v16i1.20169.

Wijayanti, N., \& Widodo, S. A. (2021). Studi Korelasi Motivasi Belajar terhadap Hasil Belajar Matematika Selama Daring. Journal of Instructional Mathematics, 2(1), 1-9. http://jurnal.stkipkusumanegara.ac.id/index.php/jim/article/view/849.

Yelvia, S. (2019). Analisis Motivasi Belajar Siswa pada Mata Pelajaran Ekonomi Bisnis di Sekolah Menengah Kejuruan Negeri 6 Pekanbaru (Skripsi), Universitas Islam Negeri Sultan $\quad$ Syarif $\quad$ Kasim https://core.ac.uk/download/pdf/300873783.pdf . 